\title{
Marcus Rediker
}

Outlaws of the Atlantic: Sailors, Pirates, and Motley Crews in the Age of Sail. Boston:

Beacon Press, 2014. xii + 241 pp. (Paper US\$19.00)

Marcus Rediker has crafted a distinguished career as a historian of maritime history from below. Though not marketed as such, Outlaws of the Atlantic is a compilation of his work, repackaged to some degree. As the title suggests, his research focus has been on the role of maritime laborers, viewed as a collective class of maritime proletarians, crucial in the making of the modern world. Over the course of his prominent career, Rediker has shifted from a relatively narrow focus on Anglo-American seamen to incorporate a richer and more nuanced historical understanding of the black experience at sea, whether as rebelling slaves in the many Middle Passages, or as members of the "motley crew" in the American Revolution. Through it all, the sea emerges as the central setting of historical processes and events from the late seventeenth century through the early nineteenth.

Whether black or white, the sailors and slaves in these chapters share the common feature of resisting and rebelling against the rise of a global capitalist order. Rediker characterizes his outlaws as Hobsbawmian social bandits and frames his analysis in the historiographical tradition of Staughton Lynd, Jesse Lemisch, Gary Nash, Alfred Young, and E.P. Thompson, to whom he dedicates the book. Of the seven chapters, two were originally delivered as keynote addresses, and the epilogue as a conference presentation. The three lengthiest chapters are reprints, with minor revision, of previously published essays from The Slave Ship (2007), The Many-Headed Hydra (2000), and his landmark article, "Under the Banner of King Death," from the William and Mary Quarterly (1981), reprinted here with a minor supplement from Villains of All Nations (2004). The opening chapter, "The Sailor's Yarn," portrays the sailor as a "global vector of communication" (p. xi), providing an alternative source of information, knowledge, and ideas to official and state-sponsored modes of communication. The next two chapters are minibiographies based on the subjects' own written accounts: Edward Barlow, a "poor seaman," portrayed here as aligned with political radicalism, and Henry Pitman, a "fugitive traitor," failed Monmouth rebel, and white maritime maroon who performs collective escape in the West Indies. The chapter entitled "Black Pirates" is slightly unexpected, in that rather than focusing on African and African-American sailors who turned to piracy (or were coerced into joining pirate crews), it explores the contemporary cultural impact, including plays, pamphlets, arts, and journalism, that emerged in the wake of the Amistad shipboard slave revolt of 1839 .

(C) KEVIN P. MCDONALD, 2017 | DOI: 10.1163/22134360-09103013

This is an open access article distributed under the terms of the prevailing CC-BY-NC license 
While the writing is often rich and seductive, readers new to Rediker's work will have to decide for themselves whether the overall thesis of a maritime proletariat collective holds water. A few problematic points struck me as salient, beginning with the preface: Rediker spins his own yarn, far from the sea, about the James brothers, the notorious ex-Confederate bank robbers, murderers, and slave owners, of whom he asserts, "they were good boys who just got into a little trouble ... or to put the point a different way, the law does not a criminal make" (p. x). In a book that attempts to reconcile race and class divisions among a seafaring collective (see Chapter 6, "African Rebels: From Captives to Shipmates"), romanticizing the James boys at the outset is a little troubling indeed. By definition, the law did make criminals, and legal institutions helped shape the Atlantic World from which his outlaws emerge. To be sure, pirates, sailors, and slaves often negotiated legal systems for their own ends, including, most famously, the Amistad slaves, who successfully won their case for freedom before the Supreme Court. And despite the argument made throughout the volume that these outlaws resisted a global capital order and that the sailors were global cosmopolitans, the geographic scope is limited to the Atlantic, mostly its northern half.

Throughout his career, Rediker has helped spur a growing body of pirate and maritime scholarship. This book serves as a great introduction to general readers unfamiliar with his work, and it would contribute well in undergraduate courses in Atlantic, maritime, and American history. For graduate courses in the same fields, it should be mandatory reading. Scholars and students will debate some of its theoretical underpinnings and perspectives, but Marcus Rediker has firmly established the sailor/seaman as a profound historical actor and the sea as the central site of historical change.

\section{Kevin P. McDonald}

Department of History, Loyola Marymount University,

Los Angeles CA 9oo45, U.S.A.

kevin.mcdonald@lmu.edu 